\title{
RETHINKING MIND-BODY DUALISM: A BUDDHIST TAKE ON THE MIND- BODY PROBLEM
}

\section{Chien-Te Lin}

This paper is an effort to present the mind-body problem from a Buddhist point of view. Firstly, I show that the Buddhist distinction between mind and body is not absolute, but instead merely employed as a communicative tool to aid the understanding of human beings in a holistic light. Since Buddhism acknowledges a mind-body distinction only on a conventional level, it would not be fair to claim that the tradition necessarily advocates mind-body dualism. Secondly, I briefly discuss a response to Cartesian dualism from a Buddhist perspective and suggest that in this particular regard, the Buddhist approach may be likened to the 'category mistake' argument formulated by Gilbert Ryle. The fact that the Buddhist view does not accord with Cartesian dualism, however, does not imply that a monistic approach to the mind-body problem such as behaviourism, physicalism or biological naturalism is necessarily assumed. The Buddhist position could perhaps be best described as a middle way approach of 'neither-dualitynor-identity'. Thirdly, I remain sceptical about the reductionist approach of accounting for mind merely on the level of brain or behaviour. In overlooking crucial ethical and axiological implications of mind, I argue that such an approach necessarily fails to impart a complete picture of mind. The Buddhist soteriological approach furthermore reveals certain law-like connections between mental attitudes and suffering which are for the most part overlooked in mainstream metaphysical explorations into the relation between mind and body. I thus endeavour to show why exploration into the link between mental phenomena, spiritual cultivation and the accumulation of karma is imperative to any comprehensive inquiry into the human mind.

\section{Introduction}

The mind-body problem is an important issue often discussed in philosophy of mind, and since the time of René Descartes the theory of mind-body dualism has received a great deal of attention. Many scholars have, however, shown that mind-body dualism is deeply problematic. Having made attempts to refute all forms of mind-body dualism, John R. Searle claims that the Buddhist approach to mind indeed constitutes a version of this theory. ${ }^{1}$ 
The distinction between mind and body exemplified by usage of terms such as name (nāma) and form (rūpa) in Buddhist scriptures, has led scholars such as Peter Harvey and Paul J. Griffiths to search for insights into the way Buddhism interprets the mind-body relationship. Both Harvey (1993) and Griffiths (1986) seem to presuppose that Buddhism advocates some type of mind-body dualism. The question we need to ask however, is whether the Buddhist distinction between body and mind necessarily implies adherence to mind-body dualism? And if so, then what kind of mind-body dualism does it represent? If this is not the case, then what precisely is the Buddhist stance with regard to the mind-body problem?

In order to answer these questions, I take core Buddhist tenets as the basis for an investigation into the Buddhist viewpoint on the mind-body problem, and, furthermore, take a look at the contributions such findings could possibly make to contemporary issues in philosophy of mind, particularly as it relates to the discussion on dualism. Rather than comment on the positions that individual Buddhist schools or contemporary philosophers hold on the matter of the mindbody problem, I wish to employ views common to all Buddhist schools of thought. $^{2}$

Adhering to neither Cartesian dualism nor material monism, I contend that the basic position of Buddhist theories of mind is at odds with a number of views commonly held in Western philosophical traditions. The Buddhist theories of designation by provisional naming (prajñapti) and relative truth (samvrttisatyatva) clearly reveal that the Buddhist distinction between mind and body is mainly for the sake of facilitating discourse. I furthermore discuss both the Buddhist viewpoint of non-duality based on the theory of middle-way and the connection between mind and karma as it relates to the mind-body problem. Although the mind-body distinction appears to be a kind of practical dualism, on the level of ultimate truth (paramārtha satya), Buddhism advocates neither mindbody dualism nor non-dualism and is therefore perhaps better referred to as 'conventional dualism'. I also point out the divergence in modus operandi between mainstream metaphysical third-person enquiries into the relation between body and mind on the one hand, and the axiological first-person approach employed in Buddhist theory and practice on the other. I conclude by showing why the contemplative approach of Buddhism is imperative to a comprehensive understanding of mind.

\section{The Buddhist Mind-Body Distinction as merely Provisional}

\subsection{Various distinctions employed in Buddhism to explain how human beings operate as a whole}

Since the Āgama sutra tells us that a Buddhist practitioner might experience physical pain, ${ }^{3}$ yet be free of mental suffering, there can be little doubt as to whether Buddhism makes use of the mind-body distinction. However, it is crucial 
to realize that the kind of mind-body distinction employed here is provisional rather than absolute. In Buddhist writings, language and concepts function merely as a temporary means to achieve a higher goal. Rather than being an end in itself, linguistic expression serves as a tool to communicate a diverse range of ideas. In addition to the distinction between mind and body therefore, we find a number of other distinctions used to convey the concept of a human being as a holistic entity. The Āgama sutra states for example, that 'consciousness' (vijñāna) and 'name-form' (nāma-rūpa) are interdependent as a whole, much like the way in which three reeds support each other in order to stand erect. ${ }^{4}$ Furthermore, the Buddha also used concepts such as the five aggregates (pañca-skandha) ${ }^{5}$ and the six roots (șad indriyāni) to refer to the integrated wholeness of a human being. A brief outline of the various mental and bodily distinctions employed to facilitate communication on a conceptual basis in Buddhism can be presented as at Figure 1.

From the chart at Figure 1, it is clear that a dualistic distinction between the mind and body is not the only distinction employed in Buddhism. Besides the twoway distinction between mind and body (or name and form), there are also threeway, five-way and even six-way distinctions. Seeing as they are all provisional, a number of distinctions are possible. The distinction between 'five aggregates' or 'six roots' merely serves as an aid to illustrate the various aspects of a human being. Although distinctions such as 'four aggregates' or 'seven roots' are uncommon in early Buddhism, a later Buddhist school, the Yogācāra, famously developed the theory of the 'eight consciousnesses' based on the original six consciousnesses and two additional consciousnesses, namely self-consciousness (manas-vijñāna) and storehouse consciousness (älaya-vijñāna). There is even a ninth consciousness found in Paramārtha's system of Yogācāra known as the stainless consciousness (amala-vijñāna).

Seeing as they are merely employed on a conventional level, these distinctions are neither fixed nor absolute. In fact, a close scrutiny of these distinctions can prove to be troublesome. For example, although 'feeling' is

\begin{tabular}{|c|c|c|c|c|c|c|c|c|c|}
\hline The mind-body & \multicolumn{5}{|c|}{ body (kaya) / matter (rūpa) } & \multicolumn{4}{|c|}{ mind (citta) / name (nāma) } \\
\hline five aggregates & \multicolumn{5}{|c|}{ material form } & feeling & conception & volition & consciousness \\
\hline six roots & eyes & ears & nose & tongue & body & \multicolumn{4}{|c|}{ intention (mana) } \\
\hline $\begin{array}{l}\text { three reeds } \\
\text { (metaphorical) }\end{array}$ & \multicolumn{5}{|c|}{ form (rūpa) } & \multicolumn{3}{|c|}{ name (nāma) } & $\begin{array}{c}\text { consciousness } \\
\text { (vijñāna) }\end{array}$ \\
\hline
\end{tabular}

\section{FIGURE 1}

The mind-boy dichotomy and related distinctions employed in Buddhism 
generally classified under the category of mind, we cannot say that the aggregate of feeling (vedanā-skandha) belongs to the category of mind alone. Although feeling is a mental phenomenon, it originates from the physical body and is therefore almost invariably accompanied by some form of physical contact with the outside world. As the theory of the twelve causal links ${ }^{6}$ in the Ágama sutra tells us, 'feeling' is conditioned by 'contact', so in this sense it is also a bodily phenomenon. At the very least, it never exists in complete isolation from the physical realm. Furthermore, the question of what exactly nāma refers to is often further complicated by interpretations of various Buddhist traditions. In early Buddhist texts such as the Āgama sutra, the concept of nāma was originally used to refer to the aggregates of feeling, perception and volition. In later texts however, this term's scope of reference usually also includes the aggregate of consciousness. ${ }^{7}$ Another example is that of nāma-rūpa, which is generally said to refer to mind-body. However, since there are many more subtle differences between the mind-body and näma-rūpa, this interpretation is only provisional. Sue Hamilton (1996, 135), for instance, thinks that a more meaningful interpretation of nāma-rūpa would be the individualizing or abstract entity of a human being. Also, as Hamilton rightly points out, the Buddha's teaching on what comprises a human being is consistently focused not on what comprises the substance of the constituent parts, but rather on what their function is and how they contribute to the complexity of human functional aspects. This point has to be borne in mind in considering the so-called 'mind' and 'body'. 8 use of conceptual distinctions such as nāma-rūpa, citta-kaya and mind-body therefore almost always requires further analysis to elucidate their full scope and intended meaning. As an expedient means of expression, the purpose of employing such terms is mainly to augment our understanding of the constitutional and functional aspects of a human being.

Hamilton (1996) suggests that in the early sutras, nāma is described as giving rise to a verbal, conceptual or abstract impression on rūpa, and rūpa is described as giving rise to a sensory impression on näma. There are thus these two aspects to the compound as a whole. The terms näma-rūpa represents a stage which one might call the 'blueprint' of the individual in terms of the concept itself and that which is being conceived. Näma provides an abstract identity for the individual as the entire conceptual identity of the individual. Rüpa in turn provides form or recognisability to the individual, in the sense of giving shape to that abstract identity which is apperceivable by means of sensory impression. Nāmarūpa is thus name and named, both of which are mutually necessary for the existence of the other (Hamilton 1996, 127). Besides, Paul Griffiths (1986, 110) points out that the mental and the physical are categories of events which are phenomenologically irreducibly different. Hence, although there is no ontological distinction between the mental and the physical, Buddhism nonetheless preserves a phenomenological distinction between the two. To quote Griffiths $(1986,112)$, Buddhism asserts 'a non-substantivist event-based interactionist psycho-physical dualism'. Every mental event brings about an effect on the level of karma, and the 
totality of these events in turn determines whether a human being attains nirvana or remains in samsara. ${ }^{9}$

In brief, the Buddhist portrayal of mind and body as two distinct aspects of a human being makes use of the mind-body distinction merely as a temporary conceptual tool to illustrate the formation of the blueprint of an individual. Seeing as Buddhism can be seen as a kind of dualism in this sense alone, Hamilton (1996, 169-170) has rightly opted to use the term 'conventional dualism' when referring to the Buddhist stance on the mind-body relation.

\subsection{Conceptual distinctions on the conventional level as an expedient means}

In his article 'Why I Am Not a Property Dualist', John Searle (2002) calls the mind-body distinction a 'conceptual confusion' $(2002,58) .{ }^{10}$ It is important to keep in mind however, that in Buddhism this distinction is employed on a conventional level. That is, the mind-body distinction functions as a provisional label. As such, it exists only nominally as a manifestation of ideas conveyed by way of designation (prajñapti) - a concept especially important in the Mãdhyamika philosophy. Rather than leading to 'conceptual confusion', this distinction serves as an expedient tool that assists in the communication of concepts related to the complex makeup of a human being.

Moreover, in Buddhist philosophy linguistic designators belong to the level of conventional or worldly truth (samvrtti-satyatva). The Sanskrit word samvrtti, is usually translated as 'conventional' and literally means 'that which is concealed'. So although linguistic designators are a convenient means through which concepts may be communicated, they also have the potential to conceal the nature of reality and therefore can be somewhat of a double-edged sword. When employed skilfully they have the potential to facilitate communication, yet when wrongly used they may also lead to a mistaken conception of the world. Seeing as attachment to concepts and discursive thought is one of the root causes why human beings remain in the cycle of samsara, skilful use of language has always been one of the main concerns of Buddhism (Streng 1967, 142).

In Mãdhyamika philosophy, much attention is given to the two levels of truth. As Nāgārjuna explains in his Mūlamadhyamakakārikā:

The Buddha's teaching of the Dharma is based on two truths: a truth of worldly convention, and an ultimate truth. Those who do not understand the distinction between these two truths do not understand the Buddha's profound teaching. Without depending on the conventional truth, the meaning of the ultimate cannot be taught. Without understanding the meaning of the ultimate, Nirvana is not achieved. (Tsongkhapa 2006, 479-498)

Conceptual distinction (vikalpa) belongs to the conventional level of truth. In the realm of ultimate truth (paramärtha-satyatva) however, there are no 
conceptual fabrications. All nominal distinctions are considered improper and must be eliminated before a person can perceive the true nature of things. Still, we cannot deny the functioning of conceptual distinctions altogether. These distinctions, although provisional, occupy a central role in conventional reality as a means to convey the meaning of ultimate reality. It is precisely this theory of the two truths that distinguishes Buddhism from other philosophies. In the Buddhist scheme of things, conceptual distinctions are acknowledged only as an expedient means on the relative or conventional level and employed for the purpose of conveying the obscured meaning of reality on an ultimate level. ${ }^{11}$

To sum up, discursive thought remains on the level of the conventional. Much like seeing a black object against a white background, its main function and purpose is to provide the kind of contrast needed on a conceptual level to form ideas. Stating the example of organic and inorganic matter, or permanent and impermanent phenomena, the Dalai Lama admitted that dualistic categories are apparent everywhere and that Buddhism does employ a certain kind of dualism (Luisi and Houshmand 2008, 181). Yet, as is clear from the theories of designation by provisional naming (prajñapti) and relative truth (samvrtti-satyava), the Buddhist use of the mind-body distinction is merely for the sake of facilitating easy communication. On the ultimate level (paramārtha), Buddhism advocates neither mind-body dualism nor non-dualism. On the conventional level, the mind-body distinction functions as a kind of practical dualism which could perhaps be most suitably referred to as 'conventional dualism'.

\section{Buddhist middle-way approach toward the mind-body problem: neither disembodied mind nor absent-mind body}

In the previous section, I argued that the dualistic distinction of mind and body is a particular type of expedient mode, but I also pointed out that this is not the only mode employed in Buddhism. I furthermore explained how the mind exists as the conceptual identity of a body, and how the body serves as a medium of sensory impression on the mind. In what follows, I shall discuss the Buddhist outlook on 'mind' and briefly touch upon its role and relation to the body. Based on these arguments, I hope to show that the Buddhist explanation of the interdependence of mind and body, or more specifically between consciousness and brain, ${ }^{12}$ is at odds with both Cartesian dualism and mind-body (mind-brain) identicalism. That is, Buddhism denies both dualistic and monistic approaches to the mind-body problem.

\subsection{Viewpoints at odds with Cartesian dualism and a disembodied mind}

The Buddhist denial of the existence of a soul or self (ätman), accords with the views of some contemporary philosophers. In his book The Concept of Mind (1949), Gilbert Ryle suggested the term 'category-mistake' in an effort to rebuke 
what he argued to be a confusion over the nature of mind born from Cartesian dualism. According to Ryle, it is a mistake to treat the mind as an independent object comprised of a non-physical substance.

One of the examples he gives is that of a visitor to Oxford University. The visitor, upon viewing the colleges and various facilities like the library and so on, reportedly inquired 'But where is the university?' In Ryle's view, the visitor's mistake is presuming that a university is something above the units of physical infrastructure, faculty, and students of this university. In actuality, however, Oxford University is nothing more than the complex conglomeration of the buildings, facilities, teachers, students, and so on. Ryle goes on to argue that the Cartesian dualism of mind and body rests on a similar category-mistake, and further suggests that there is no mind and body as two, but instead only a mind of a body (Ryle 1949, 16-18).

In Early Buddhism, we find arguments related to the theory of non-self (anätman) that not only accord with Ryle's argument about the 'category-mistake', but are also equally effective at refuting Cartesian dualism. Take the simile of the word 'chariot' explained in the Milindapabha for instance, where the term 'self' is compared to the term 'chariot'. The word 'chariot' is simply a name or an expression imputed on the collection of its parts - the axle, wheels, pole, reins, yoke, and so forth. The simile is used to show that there is no independently existent self and that the term ' $I$ ' is merely a convenient designator. ${ }^{13}$ That is, when there are the aggregates, we conventionally take this to imply 'being' and then use certain provisional terms to refer to it. Similarly, the term 'mind' is merely an imputed name (näma), much like the name 'Oxford University'. Apart from the infrastructural parts, it is not possible to pinpoint an independently existing entity such as 'Oxford University'.

Some might claim that the Buddhist theory of rebirth (samsāra) appears to imply the continuation of an individual soul once the body ceases to exist. The Buddhist theory of non-self however, is specifically a counter-argument to the view that rebirth implies mind-body dualism. ${ }^{14}$ It is true that some Buddhist schools developed certain concepts that seemingly imply a rebirthing entity such as the bhavanga-citta ${ }^{15}$ proposed by the Theravādins', the pudgala ${ }^{16}$ of the Pudgalavādins', or the âlaya-vijñanna ${ }^{17}$ of the Yogacārins. Although they did this in an effort to justify the Buddha's moral teaching and to lend credence to the theories of karma and rebirth as well as our experience of selves and persons; their views never contradicted the most fundamental tenets of Buddhism according to which all things are impermanent and empty of inherent existence. Things arise in a manner similar to the temporary arising of a bubble or a flash of lightening ${ }^{18}$ and can only be said to 'come into being' under the laws of interdependent-arising. More specifically however, these concepts never contradicted the doctrine of nonself.

Rather than admitting to an eternal soul which migrates from one birth to the next, Buddhism instead posits the existence of a 'stream of consciousness' or 'mental flow' which is nothing more than the changing continuity of a person's 
karma. When a person dies, his karmic recipient state temporarily reaches an end, but this karmic energy continues into the next birth. Unless the state of nirvana is attained, this karmic energy will once more take shape as a new karmic recipient entity in accordance with the individual karma and common karma accumulated during that lifetime. Since during the rebirth process, consciousness is the agentive element or medium of the karmic continuity in time, it is often called 'karmically-resultant-consciousness' (vipāka-vijñāna). Virtuous states of mind create positive karma, while non-virtuous states lead to negative karma. The quality of our mental state is therefore of paramount importance. Learning to tame the mind and make it serviceable enables a person to turn away from unwholesome mentality, which makes it possible to purify one's karma and break out of the cycle of continuous rebirth. This karmic mind or consciousness which continues into the next life however cannot be viewed as a 'soul,' but merely as a provider of a sense of continuity in a changing process. To view it as a 'soul' would carry the implication of an innate, eternal, static, and unchangeable entity. In the Āgama and Nikaya sutras, Buddha specifically refuted the monk Sati's proposition of consciousness as an abiding soul (Hamilton 2001, 86).

Rebirth could perhaps be compared to the rise and fall of nations in history. Take the example of the last Chinese empire, the Qing dynasty, and the Republic of China which was born when this empire came to an end about a century ago. What is the relation between a former nation and its successor? Are they the same or entirely different? According to the theory of emptiness, on the ultimate level of truth, there is no unchanging independently existing entity to be established in either case. Hence, we cannot reasonably claim them to be exactly the same. However, on the level of relative truth, things come into being due to the workings of cause and effect, and we cannot deny the continuous process of becoming and vicissitude. It would therefore also be wrong to claim that they are entirely different. As Ven. Nyanaponika Thera explains, the process of karmic rebirth excludes sameness of the ego-identity of a transmigrating soul and also excludes absolute diversity between the former and the subsequent existences. It is the karmic energy inherent in the conditions that creates continuity. In this continuous process there is no complete identity or diversity, and in every phase of assimilation there is an irreducible remainder of diversity making for dissimilation, and in every phase of dissimilation there is an irreducible remainder of identity making for assimilation (Nyanaponika 1998, 43-45). Therefore, rebirth in subsequent existences could be understood as the continuation of a dynamic, ever-changing process of karma rather than that of one being transmigrating or incarnating from one existence to the next.

The idea of rebirth remains a controversial matter with many possible interpretations offered even within the Buddhist tradition. For instance, Buddhist scholar Peter Harvey suggests rebirth ought to be seen both as a process which takes place after death and also as a process taking place during life. Since we are constantly undergoing change over the progression of a lifetime, he believes that we are in a sense constantly 'reborn' as a 'different' person according to our 
various moods, and we may experience 'heavenly' or 'hellish' states of mind depending on how we act. This continuous process of change, determined by the nature of our actions, does not abruptly stop at death but carries on (Harvey 1990, 45-46). Some Buddhist scholars even claim that the idea of rebirth is not a core Buddhist teaching and one does not need to adhere to it in order to be a Buddhist (See Keown 2000, 43). Others have gone even further by saying that the idea of rebirth contradicts the teaching of the Buddha. ${ }^{19}$ Then there are also those who put forward what is known as 'naturalized Buddhism' in an effort to rid the tradition of mysterious concepts, such as rebirth in particular (see Wright 2005, 78-93). On the opposite end, we find scholars who have made great efforts to prove that rebirth is real (see Stevenson 1980, 2000; Tucker 2008).

Yet other possible interpretations of the concept of rebirth include various dimensions of existence, parallel universes or simply varying states of mind. Nonetheless, this brief introductory treatment of the subject is merely intended to show that the Buddhist theory of non-self stands in obvious contradiction to Cartesian dualism. While in future research I hope to further dig into the complex matter of rebirth, for the moment it suffices to say that admitting to a continuation of a person's mental components governed by the law of karma does not mean that one adheres to the views of a Cartesian dualist.

\subsection{Viewpoints at odds with material monism and mindless body}

The mystical theory of 'a ghost in the machine' originally propounded by Cartesian dualism has been gradually replaced by more rational and scientific approaches such as behaviourism. As mentioned earlier, the argument of the 'category mistake' against Cartesian dualism does accord with the Buddhist outlook, yet this does not mean to say that behaviourism necessarily offers a better solution to the mind-body problem. The Buddhist standpoint is certainly not compatible with the claim that mind or consciousness can be reduced to body or brain, as advocated by proponents of physicalism, biological naturalism and so forth. Seeing as these theories have received much attention in the current scientific age, I'd like to briefly respond to them from a Buddhist perspective in an attempt to point out some differences between Buddhism and psycho-physical identicalism or material monism.

Although we rely upon the colleges, institutes, facilities, faculties and students of Oxford University in order to gain an understanding of the concept 'Oxford University', the constituent parts that make up this concept constantly change with the passage of time. Since they remain in a state of vicissitude, and constantly undergo increase and decrease, expansion and reduction, the concept 'Oxford University' is founded on a fleeting base. This line of reasoning applies to most other abstract concepts, such as 'book' and 'pen' for example, each of which has a great many possible references and therefore can never really be defined exactly at any specific point in time. Pens and books of various kinds have appeared on the market in the past and many more types will be designed in 
future. Regardless of their colour, size, shape or the type of material they are made of, we refer to all 'pens' and 'books' with the same conventional designation. Hence, neither concepts based on physical phenomena nor concepts based on nonphysical phenomena can ever really be permanently established. The Buddhist theory of impermanence clearly explains the principle of constant change which implies that neither physical nor purely conceptual entities can ever truly be said to have any unchanging substantial existence. It is therefore critical that we are especially vigilant during the process of conceptualization so as to avoid attachment. Seeing as neither the concept of 'mind' nor any behavioural states that we observe on a physical level can be established as truly existing from their own side, any theory which equates the concept of mind to nothing more than physical behaviour would be troublesome. Even more troublesome however, is perhaps the common counterargument that it is not always possible to find physical behaviours that correspond exactly to an endless variety of abstract mental concepts.

While behaviourists claim that no mind exists apart from physically observable behaviour, the majority of materialists or physicalists subscribe to a version of monism in their bid to account for the obvious presence of both mind and consciousness. Both theories attempt to simply explain away mental phenomena, with an extreme physicalist being happy to contend that we are no different to 'zombies'. But the claim of 'zombies' wholly contradicts the Buddhist view on mind and body according to which consciousness is deemed necessary for the continued existence of a sentient being. Concepts such as 'food that sustain consciousness' (vijñāna-ähära) along with the 'three compulsory life conditions' of consciousness (vijñāna), life force (jīita), and heat (ūṣman) all support the view that our existence cannot be radically severed from conscious experience. Given that most people are endowed with conscious experience under ordinary circumstances, human consciousness is accepted as a given premise.

John Searle recently put forth his theory of biological naturalism, claiming that mental states are simply brain states, rather than being something 'over and above' brain processes. As he puts it, 'all of our mental phenomena are caused by lower level neuronal processes in the brain and are themselves realized in the brain as higher level, or system, features' (Searle 2002, 57). To Searle then, the mind is a higher-level property of the brain, and the neurons comprise the lowerlevel of the brain. Whilst viewing the mind as caused by neural activity, he simultaneously considers mind to be merely a feature of neural activity. One explicit implication of this view is that the mental, though not physical, is indeed biological. Hence Searle believes it is a mistake to divide the universe into the physical and the mental, since practically everything falls into the categories of the physical or biological. It just so happens that there are both 'mental' physical objects and 'non-mental' physical objects (2002, 61-63).

Searle not only objects to the dualistic point of view that consciousness somehow exists 'over and above' the brain, but he also argues against the views of 
materialism. From the perspective of materialism, consciousness is seen as 'nothing but' behaviour or computational states, hence the existence of inner states, qualitative states and subjective mental phenomena is denied altogether. In Searle's view, dualism complicates matters by postulating a separate mysterious realm of the mental, while materialism mistakenly denies the existence of consciousness. Searle $(1998,47-54)$ offers his own theory of biological naturalism as an alternative to these two theories. Since this theory implies that consciousness is nothing more than a function of brain, we could say that Searle considers conscious states as being identical with brain states. That is, mental phenomena are viewed as nothing more than biological phenomena such as digestion, photosynthesis, or the secretion of bile. ${ }^{20}$

Now the question is: is Buddhism compatible with the view that mental processes are merely a biological function of brain? Searle views the relation between the brain and the mind as analogous to the relation between the stomach and digestion. And he takes this argument to be sufficient justification for his theory that mind is a biological phenomenon similar to digestion being a function of the stomach. The Buddhist view however, does not agree with this type of identicalism, since it does in fact see mind as something existing over and above mere biological states. Reducing mind to the level of the physical or the biological, means that a crucial aspect of human beings is overlooked. Although mental processes can be viewed as biological functions founded on the physical, we cannot deny that the human mind has an axiological aspect. It is this very aspect of mind that is of greatest importance in Buddhist discussions of philosophy of mind. The quality of mental phenomena such as feeling, perception, volition, intention and consciousness plays a crucial role in the process of becoming liberated from samsara and of attaining nirvana. Reducing mental states to biological states wholly neglects this aspect of human existence.

Mind has axiological features in addition to its physical or biological features. Abstract concepts may perhaps be subdivided into two categories: one which is based on concrete objects which may be experienced directly via the senses, such as 'chariot', 'book', 'pen', 'desk', 'classroom' and 'student'; and another involving non-substantial things which may not be directly observable, such as 'justice', 'courage', 'goodness' and 'beauty'. While the first is essentially descriptive, the second could perhaps be said to be evaluative in nature. In my opinion, the concept of mind falls in between these two categories. Although mind as an abstract concept bears reference to physical aspects such as biological functioning (aspects which can be perceived directly and described in objective terms), in addition to this physical or biological functioning, our state of mind also carries karmic consequences. This is a point I shall elaborate on in section 4. 
3.3 A middle-way approach: toward the mind-body problem via neither duality nor identity

Both John Searle and Gilbert Ryle object to Cartesian dualism, arguing that there is nothing existing over and above the brain or behaviour. Searle sees dualism as a 'conceptual confusion', while Gilbert Ryle instead considers the mind-body distinction a 'categorical mistake'. Buddhism does side with both Searle and Ryle in their rejection of Cartesian dualism, yet this does not mean that the Buddhist outlook accords with the theory of mind and body propounded by either Searle or Ryle.

The Buddhist position with regard to the mind-body problem can be described as 'neither same nor other'. Although it would be wrong to say that the mental state is merely a brain state and that there is nothing over and above the brain processes, it would also be incorrect to hold that there is something decidedly separate from the biological brain process. Just as a reference and its referent are neither identical to nor different from one another-e.g. the designation 'book' is neither identical nor different to an actual book-so mind and body/brain are neither identical to nor different from one another. For this reason, within the Buddhist scheme of things neither an absent-minded body (such as a zombie) nor a disembodied mind (such as a soul) would be a reasonable hypothesis. Put differently, Cartesian dualism admits to a soul or self (ätman) apart from the physical body, thus tending towards the extreme of eternalism ${ }^{21}$ rejected by the Buddha. Material monism on the other hand, holds that the mental and the physical are of the same nature, so that nothing remains once the physical body has ceased to exist. This view would again lead to the other extreme of nihilism. ${ }^{22}$ The chart at Figure 2 aims to give a schematic representation of how the Buddhist point of view seeks to avoid these two extremes:

From the perspective of dualism, minds can continue to exist apart from bodies even after the 'conscious entity' has left the body. From a Buddhist viewpoint this causes one to fall into the trap of eternalism, where one mistakenly believes that either the mind or body can exist independently from its own side. Monism, on the other hand, claims that mental states are simply brain states, a view which again causes one to fall into the trap of nihilism, where one mistakenly believes that the reality of mind and consciousness can be disregarded altogether. In matters related to the mind-body problem therefore, the Buddhist position takes a middle way approach in assuming neither the views of dualism nor monism. $^{23}$

\section{The karmic mind: why Buddhism views mind as being more than merely brain}

\subsection{The mind and its relation to karma}

In Buddhism, 'mind' is an abstract concept used to refer to the aggregates of feeling (vedanā), conception (saṃjñā), volition (samskāra) and consciousness 
(vijñäna). It may also refer to related phenomena such as conscience, cognition, rationality and so forth. Whatever it may be, mind's references are invariably linked with the concept of karma. That is, every occurrence of will, reasoning, sensation, ideas, and so on is crucial to and forms part of the process of karmic accumulation. The Buddha highlighted the significance of karma in the Ägama sutra: 'I declare karma of intention as the most blameworthy. ${ }^{24}$ Regarding the relation between intention and karma, the Buddha spoke the following words: 'It is intention (cetanā), O monks, that I call karma' (A.Ill.415, as quoted in Harvey 2000, 17; see also Gombrich 1971, 246). With unintentional behaviour having less of a karmic influence, it is easy to see why mind occupies such an important place in Buddhist philosophy. ${ }^{25}$ The existential status of mind is like the existential status of karma. While karmic effects manifest after they have been created by virtuous or nonvirtuous states of mind, karmic actions also leave an imprint on an individual's mind which will eventually manifest on the material plane through the body.

As Paul Griffiths $(1986,109)$ correctly points out, only mental events can be ethically qualified as good or bad and therefore only mental events can be productive of karmic effect. The quality of mental states is a central concern in Buddhism. In the Abhidharma texts in particular, special importance is given to knowledge arising from the analysis of mental states. Hence we find that elaborate theories and systems of classification have been developed in both the Abhidharma tradition and the philosophical literature of the Yogacāra, where various wholesome and unwholesome states of mind are thoroughly analysed so as to offer not only a clear classification of the various qualities of mind and consciousness, but also to adequately stress their importance. The aim is to gain a clear understanding of the mind, so as to realise the origin of unwanted mental states such as greed, anger, arrogance and ignorance. For in order to achieve the perfected moral character of an enlightened being, these negative states shall first have to be overcome.

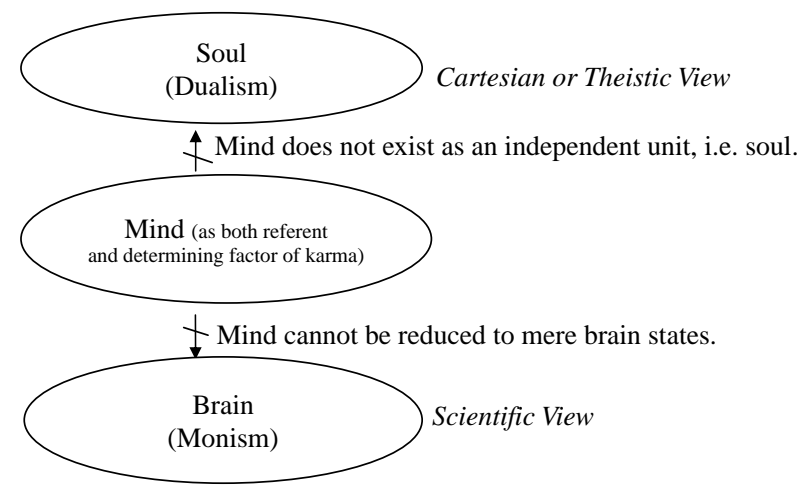

FIGURE 2

The Buddhist 'middle-way approach' to the mind-body problem 
In short, in Buddhism the concept of mind does not carry merely physical or biological significance, it also has a particularly strong axiological relevance. Through becoming aware of the workings of mind and its relation to karma, it is possible to learn to transform destructive states of mind. Continuous mental purification eventually leads to a state known as nirvana, which is the cessation of suffering. A disturbed mind on the other hand, remains in a state of perpetual suffering and will therefore never be free from the bondages of karma. While modern research has consistently focused the cognitive and epistemological aspects of mind, Buddhist philosophy attaches far greater significance to the moral and soteriological aspects of mind along with their relation to karma. From a Buddhist perspective then, viewing the mental as nothing more than a brain state neglects crucial aspects of mind and prevents us from ever gaining a full understanding of mind and its workings.

\subsection{Karmic accumulation during the process of enactive cognition}

Recently embodied cognitive science follows pragmatism and phenomenology in viewing perception and cognition to be understandable only in terms of action in the environment. They argue that cognition should be described in terms of agent-world dynamics rather than in terms of computation and representation. For instance, in the book Neither Brain nor Ghost, W. Teed Rockwell (2007) applies the insights of pragmatism to argue that the human mind is not reducible to the brain, nor to the nervous system, nor even to the human body. He argues that understanding the mind as an interacting nexus_or a 'behavioral field' —of the nervous system, the body, and the world supports the new cognitive science paradigm of dynamic systems theory. He claims that the physical base of the mind is not the brain but in fact the brain-body-world nexus. ${ }^{26}$ In Supersizing the Mind, Andy Clark (2008, xxviii) also argues that our thinking doesn't happen only in our heads but that 'certain forms of human cognizing include inextricable tangles of feedback, feed-forward and feed-around loops: loops that promiscuously crisscross the boundaries of brain, body and world. ${ }^{27}$ He thus advances a conception of mind that is extended rather than 'brain-bound'.

The Buddhist standpoint agrees with the enaction point of view that body together with its interaction with environments form our mind and cognition. Mental phenomena thus come about through recurrent interaction between cognitive subject and its broader natural or social environments. But Buddhism also further suggests that when we interact with the world, we not merely cognize objects and organize knowledge, we also accumulate karma. That is, while the mind functions as the behavioural field of the brain, the body, and the world; karmic accumulation lies low in the course. Karma is created when a particular mental state combines with an intentional behaviour which leads the agent to interact with the world. The process during which a conscious body encounters any certain environment, therefore, is also a process of karmic formation. 
Buddhism is concerned precisely with this karmic formation amid the interacting nexus of the brain-body-world.

Free will enables us not only to choose good actions over bad ones, but also allows us to focus our attention on the object of our choice. By choosing to focus on our mental states and attitudes, we naturally raise our awareness of how we interact with our environment and thereby progressively gain more control over the type of karma we continuously create by way of such interaction. Positive mental states create good karma, while negative mental states create bad karma. Mind therefore is not only a tool used to acquire knowledge with, but also a key determining factor in the quality of our karma. It should therefore come as no surprise that the core teachings of many Buddhist traditions revolve around the practice of mindfulness. The renowned contemporary Buddhist master Thich Nhat Hanh placed much emphasis on precisely this practice. The Buddha himself also encouraged his students to master themselves, truly live in the present moment and always remain mindful of how they conduct themselves (Nhat Hanh 2007). In order to stop creating bad karma and start accumulating good karma, it is necessary to first transform our ignorance, attachment and discursive thoughts into positive mental states such as compassion and the wisdom of emptiness. And in order to accomplish that, we need mental training and spiritual refinement.

To sum up, since the process of enactive cognition unavoidably entails the process of karmic accumulation, Buddhism pays close attention to the matter of karma when considering the cognitive activities of human beings. The difference in cognitive activity between an ordinary person and a liberated being (arhat) is that when a liberated being perceives a flower, he/she sees just that-a flower. An ordinary person, however, sees more than just a flower, giving rise to thoughts of like or dislike towards the perceived object. Ignorance of reality and attachment (or aversion) towards perceived objects are features of ordinary consciousness. Because a liberated being has overcome ignorance regarding the true nature in which things exist, he has transcended both attachment and aversion towards objects and is thus no longer bound by the karmic effects of attachment and aversion. The difference between seeing reality as it is (truly knowing) and seeing a distorted version of reality (knowing, but not really knowing) can perhaps be highlighted as one of the main differences between a liberated being and an ordinary person. For this reason, ridding oneself of ignorance-the root cause of both attachment and aversion-is one of the main goals of Buddhist spiritual practice.

\subsection{The role of mental cultivation in pursuit of a life of value}

We have already established that from a Buddhist perspective, mind and body (or mind and brain) are neither different nor identical. In claiming that mind and body are not different, Buddhism essentially propounds that there is no self or attman; and in claiming that they are not identical, the principle of karma is affirmed. In matters of the mind, the Buddhist outlook does not only consider the 
physically observable, but also takes actualization of value into account. It therefore does not accord with physicalism, behaviourism or biological naturalism.

One way to explain the relation between body and mind is the example of a painting and an experience generated by looking at the painting, such as the experience of beauty, for instance. A physicalist would argue that there is no beauty apart from the painting itself. He thus reduces the experience of beauty to a mere combination of various material elements such as colours, textures, shapes and lines, thereby effectively explaining away the factor of beauty. This however violates our actual experience of beauty. On the other hand, we also cannot reasonably claim that the experience of beauty exists independently of the colours and materials that constitute the artwork. For if this were the case, we would have to consistently experience beauty-even when looking at nothing or looking at a less aesthetically pleasing object. So although the painting is instrumental in the experience of beauty, it is itself neither identical to nor different from the beauty experienced. Therefore, it can be argued that mind is to body, what beauty is to the painting. Just as beauty is neither identical with nor different to the painting, so too mind is neither identical with nor different from the body or the brain. ${ }^{28}$

So we see that because mental states are seen as neither equivalent nor reducible to brain states, the Buddhist view clearly disagrees with the mind-brain identity theory. While the brain is simply a biological concept referring to a physical organ, 'mind' has both a moral and a spiritual connotation. In Buddhist philosophy, the pursuit of value and creation of a meaningful life take precedence over a mere understanding the physical world. Since the actualization of value and meaning in our lives very much depend on the quality of the psyche, the spiritual aspect of human existence is valued equally, if not more highly than the material aspects. Perhaps we can say that the reductionist attitude of science explains mind from the bottom up, while the explanation Buddhism offers is one that proceeds from top to bottom. There is a vast difference between these two approaches. To Buddhists, the existence of the mind is seen as an undeniable reality, and it is upon this very premise that the inquiry into the value and meaning of life is founded.

Besides focusing on metaphysical explorations such as mental representation and mental causation alone, current philosophical inquiries into the mind could perhaps also gain useful insights from exploring the ethical and axiological dimensions of mind. To state one example, current scientific explorations into the mind rarely, if ever, look into the issue of 'mental quality'. According to the Buddhist view, achieving quality of mental state requires the elimination of the three poisons (trivisa): greediness (räga), hatefulness (dveșa), and ignorance (moha). Once the three poisons have been removed, it becomes possible to realize a level of right mindfulness and clear awareness which opens up the path to end suffering. In Buddhism therefore, this type of mindfulness and heightened awareness is viewed as a healthy mental state. It is perhaps also 
worth pointing out that the Buddhist system of mental training allows for enhancement of our mental capacity and increased happiness without the need for a fully developed, comprehensive system of biological or physiological knowledge on mind. The key lies in skilfully applying the conscious mind to all aspects of daily living. This is similar to the way in which one would skilfully train or apply one's eyes to perceive objects more clearly or perhaps work on one's rhetoric skills to become a better orator.

In brief, Buddhism takes as its main aim the skilful application of mind in order to help the agent lead a good life. Seeing as mind is a matter of morality and value, Buddhist philosophy attaches great importance to spiritual practices which aim to increase the mind's ability to cultivate virtue. ${ }^{29}$ Our quest to gain a thorough understanding of the human mind therefore ought not to be restricted to matters concerning the mind's increase of propositional knowledge alone, as is perhaps the case with the majority of current scientific studies on the subject. It is equally important to look into the mechanisms that bring about increased awareness and serenity, a state which may only be attained through continuous practise and skilful application of the conscious mind. ${ }^{30}$

\subsection{Towards a more encompassing view on the mind-body problem}

Rather than becoming consumed with the question of 'what' mind is, over the course of history Buddhist philosophers have consistently focused on the functions of the mind and looked for ways to render the mind serviceable in order to attain liberation. By making the mind serviceable, certain accomplished practitioners not only raised their awareness of the world around them but furthermore gained insights into the nature of all things, thereby realizing the state of enlightenment. Even when metaphysical and epistemological theories of mind arose after the Buddha's passing with the development of the Abhidharma method, the main concern of Buddhism has nonetheless been primarily axiological or soteriological in nature. We can thus see that there is a clear link between gaining an understanding of the mind in its current state and mental cultivation for the sake of attaining liberation.

With Buddhist considerations of mind being mainly axiological in nature, it is possible to assume a number of angles on matters related to karmic accumulation and how this process factors in shaping the behavioural field of the brain, body and environment. The various contexts in which problems of mind (and body) can be discussed are shown at Figure 3.

The approach modern science and Buddhism take on this subject differs greatly. In modern academics, where positive science dominates, research into the mind and body is done mainly in the fields of physics, biology, physiology and neurology. In Buddhist philosophy and psychology, however, mind and body have always been viewed in terms of their relation to the practical dimensions of morality and spiritual growth. The ancient Indian parable of the 


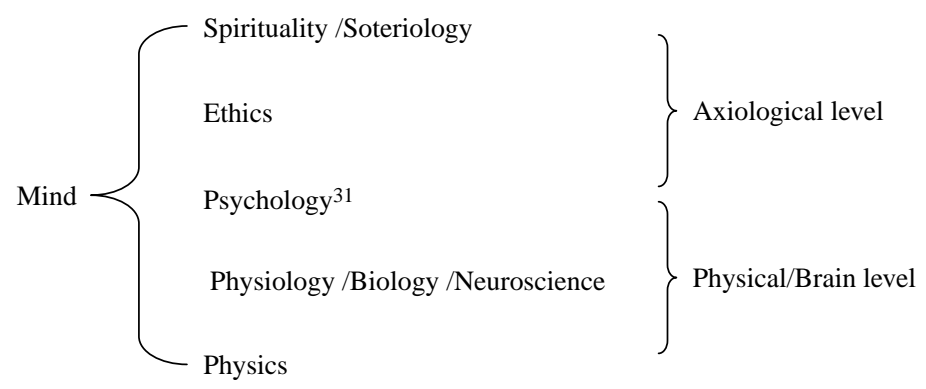

\section{FIGURE 3}

Various contexts for the discussion of problems of mind

blind men and the elephant' could perhaps be used to better explain these two diverging approaches. As a group of congenitally blind men stood facing an elephant, they experienced trouble gaining a comprehensive understanding of the shape of the animal due to its sheer size. As they moved their hands along the animal's body, each man used his own frame of reference to develop his own unique concept of 'an elephant'. Similarly, the various approaches to mind-be it physical, biological, psychological, or even ethical-are all influenced by specific background knowledge or certain cultural traditions. It is certainly possible to study the mind from 'physical', 'biological', 'physiological', 'psychological', 'ethical', or 'spiritual' perspectives, ${ }^{32}$ yet it is important to bear in mind that each approach comes with its own set of presuppositions which might cause a researcher to focus more on certain aspects while neglecting others. Integrated studies of the mind that incorporate both Buddhist theory and scientific discovery have recently received increasing amounts of interest. I believe that such undertakings have the potential to bring us to a more encompassing understanding of the human mind.

Another point worth mentioning in this respect, is that science alone is incapable of fully explaining the problem surrounding the meaning of life, particularly as it relates to the actualization of true happiness. From a Buddhist perspective, true happiness or the definite cessation of suffering can be attained only through proper training of the mind and body in order to achieve a correct view on the nature of all phenomena. The different ways in which science and Buddhism treat mind and body can perhaps be illustrated as per Figure 4.

While the diagram merely aims to provide a provisional division between explanan (explanation given) and explanandum (phenomenon being explained), it shows that mind and body fall in between the realms of value on the one hand, and matter (or biochemistry) on the other. The question of 'what is' can be explained through the disciplines of physics, biology or physiology, and neuroscience since they are based on a study of the physical or biological aspects of mind and body. The Buddhist approach on the other hand focuses on questions of value, thus providing useful insights into the practical matter of 'how to'. This approach not only offers 


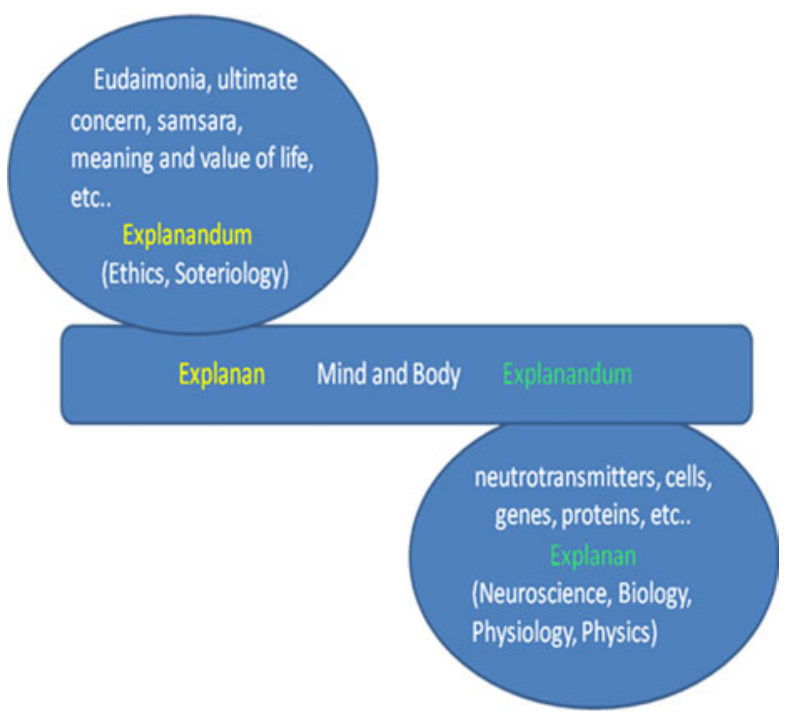

\section{FIGURE 4}

Two approaches to the problem of mind and body

general guidance on how to do good and eradicate evil, it furthermore opens up the possibility to actualize supreme goodness. The strong ethical significance that underlies the Buddhist analysis of psychological phenomena points to an undeniable link between a person's state of mind and the occurrence of either virtue or vice. With liberation being the ultimate concern, the actualization of nirvana is to be sought through refinement of the agent's mind and body. This stands in stark contrast to the viewpoint of modern academics, where mind is mainly seen as an explanandum or phenomenon awaiting further explanation. As a result, most endeavours in neuroscience and physiology come up with ever increasingly complicated analyses and interpretations of mind.

There are some serious question marks over the ability of modern science to fully explain the problem of value and guide us toward a meaningful existence. As Owen Flanagan (2007) noted, the really hard problem is explaining how meaning is possible in the material world. Buddhism suggests that meaning can be pursued and ultimately realized via two paths: wisdom, which brings an understanding of the workings of mind; and compassion, which is essentially the refinement of our mental state. Therefore, someone who has undergone mental training aimed at increased concentration, insight, perceptive abilities or awareness, is not only able to react better to his daily environment, but he or she is also much better equipped to overcome character flaws, improve personal integrity and even increase personal happiness as a result of mental training. ${ }^{33}$ All this is an augment to a person's quality of life. A more integrated approach to researching mind would therefore furnish us with a better picture of all the 
facets of the human mind and hopefully eliminate the limitations posed by specific cultural contexts and cognitive schemas. In addition, gaining a better understanding of the axiological aspects of mind makes it possible to enhance the happiness of the human race as a whole.

\section{Conclusion}

In this paper, I presented the mind-body problem from a Buddhist perspective and argued that the subject is highly relevant to Buddhist theory and practice since matters related to mind and body are closely linked to a person's attainment of nirvana or his continued existence in samsara. Buddhist views on the subject of mind may have led various Buddhist traditions to develop a number of different theories. However, rather than try to represent the positions of each school, I focused on possible inspirations that may be derived from the general Buddhist view as it relates to the mind-body problem. My findings can be summed up as follows:

With regard to the question of whether or not Buddhism can be said to advocate mind-body dualism, I have shown first that according to the theory of the two truths, a dualistic distinction between mind and body is acceptable on the conventional level, but not on the ultimate level. Such a distinction is merely employed as an expedient means to aid the discussion and understanding of a human being in a holistic light. I also showed that the dualistic distinction is not the only way in which the various aspects of a person can be analysed in Buddhism - there are also three-way, five-way and six-way distinctions. So although in a certain sense we could say that Buddhism employs a dualistic distinction between mind and body, apart from this type of conventional distinction it would not be fair to claim that it advocates mindbody dualism.

Second, I briefly discussed a possible Buddhist response to Cartesian dualism which may be likened to the argument of a 'category mistake' put forward by Gilbert Ryle. Although the Buddhist view does not agree with Cartesian dualism, it does not follow that it necessarily assumes any monistic approach to the mind-body problem as is the case with behaviourism, physicalism or biological naturalism. The Buddhist position could perhaps be best described as a middle way approach involving 'neither-duality-nor-identity'.

Lastly, I have argued against a reduction of mind to the physical level of brain or behaviour as a complete portrait of mind, because it fails to take into account ethical and axiological implications of mental functioning. The practical firstperson approach of Buddhism to mind purports to reveal various law-like connections between mental attitudes and suffering (and conversely, mental attitudes and enlightenment) which cannot be ignored in any exploration of the 
human mind. During the process of enactive cognition, mental phenomena such as feeling, perception, will and conscience play a major role in the accumulation of positive and negative karma. Spiritual cultivation of mind therefore occupies a particularly important place in Buddhist theory and practice. Contrasting strongly with purely metaphysical explorations into the relation between mind and body, the Buddhist axiological approach to the mind-body problem is very much worthy of notice and further exploration.

\section{NOTES}

1. In his book Mind, Language, and Society, Searle $(1998,49)$ mentions the Dalai Lama's assertion that 'each of us is both a mind and a body'. He therefore considers the appeal to mind-body dualism a 'multicultural' phenomenon, rather than being limited to Western culture alone $(1998,52)$.

2. In order to avoid certain disputes among the various schools, I draw on general teachings which represent the Buddhist tradition as a whole. To this end, I use some of the earliest teachings recorded in the Ägama sutra as the basis of my contentions and draw on teachings from the later Mädhyamika school as an augment to my interpretations.

3. Chinese Electronic Tripitaka Collection, T02, no. 99, p. 33, b19.

4. Ibid., p. 81, b4-7.

5. The five aggregates are form (rūpa), feeling (vedanā), conception (samjñā), volition (samskära), and consciousness (vijñāna).

6. The 12 causal links explain the continuation of the cycle of suffering and rebirth (samsāra) in detail, describing a causal connection between the subsequent characteristics or conditions of cyclic existence, each one giving rise to the next. In order of succession, they are: ignorance (avidyā), formations (sampkāaras), consciousness (vijñāna), name and form (nāmarūpa), the six sense bases (șadāyatana), contact (sparśa), feeling (vedanā), thirst (trṣnā), clinging (upādāna), existence (bhava), birth (jāti), old age and death (jarā-marana). For a more detailed introduction, see Harvey 1990, 54-57.

7. Harvey 1993, 32.

8. In Buddhist writings the focus is on questions of 'how' rather than 'what'. In emphasizing pragmatic concerns over purely theoretical ones, the predominantly soteriological approach of Buddhist theory precludes popular kinds of dualism such as substance dualism and property dualism. Take Cartesian dualism for instance: although the English terms 'body' and 'mind' may have substantialistic connotations, both Harvey and Hamilton suggest that terms such as pañca-skandha and näma-rūpa are merely convenient verbal conventions that carry no substantialistic or ontological implications. In Early Buddhism, there is no dualism of nāma (as a mental substance) versus rūpa (as a physical substance): Harvey 1993, 39; and Hamilton 1996, xxix.

9. The relation between mind and karma will be discussed in section 4 . 
10. Searle considers the contrast between the mental and the physical, the mind and the body, the soul and the flesh to be confused and obsolete, and this conceptual confusion needs to be overcome: Searle 2002, 58.

11. Aside from the two truths, the teachings on non-duality (advaya) and pursuit of non-discriminating wisdom (nir-vikalpa-jñāna) also clearly indicate that Buddhism does not propound dualism. Both non-duality and non-discrimination are prominent concepts discussed in the core teachings on emptiness, the middle way, dependent arising, provisional names and so forth. According to the teachings on emptiness and dependent arising, all things are empty of an inherent nature and the discursive reality we ordinarily experience is the outcome of causes and conditions. It is therefore not possible to establish an independently existing body, or an independently existing mind. All things arise interdependently as the effects of causes and conditions.

12. For ease of discussion, I shall stick to the terms 'mind' and 'body' in this paper. However, it ought to be noted that by 'mind' I also mean 'consciousness', and by 'body' I also mean 'brain'.

13. For a more detailed discussion of this simile, see Siderits $2007,52-56$.

14. It is precisely the philosophy of the 'selfless' person and the 'selfless' mind that puts Buddhism at odds with Cartesian dualism. Regarding to the philosophy of selflessness and how it may cohere with the ideas of rebirth and karma, please see Collins 1982, and Harvey 1995.

15. The bhavariga-citta is the state of mind that serves as a latent life-continuum or ground of becoming. It plays a crucial role in preserving the continuity of mental activity and is used to explain the living continuity of the personality. For a more detailed introduction, see Collins 1982, 225-261, and Harvey 1995, 162-166.

16. In the literature of Early Buddhism, a person (pudgala) is said to be that which continues from one life to the next. The entity that reincarnates as an individual is therefore not considered to be a 'soul'. For a discussion on this particular topic, see Thiện Châu 1999.

17. According to the philosophy of the Yogācāra school, the ālaya-vijñanna is the eighth consciousness. Being the substratum or 'storehouse' consciousness, it acts as a storehouse to retain past experience and karmic actions. From it the remaining seven consciousnesses arise and produce all present and future modes of experience in the process of rebirth. At the moment of enlightenment, the allaya-vijñana is transformed into the Perfect Mirror-like Awareness of the Buddha.

18. The Diamond Cutter Sutra states that all composite things (samskrta) exist in a manner similar to a mirage. For this reason, Buddhist practitioners are encouraged to view all things in a similar manner during meditation which aims to familiarize oneself with the nature of reality. (See Vajracchedika Prajñāpäramitā: As stars, a fault of vision, as a lamp; a mock show, dew drops, or a bubble; a dream, a lightning flash, or cloud; so should one view what is conditioned: Conze 2001, 68). 
19. Renowned Thai monk Buddhadasa Bhikkhu wrote an article Anatta \& Rebirth on this subject which ended up being spread widely on the Internet.

20. In Searle's words: 'A useful distinction, for certain purposes, is to be made between the biological and the non-biological. At the most fundamental level, consciousness is a biological phenomenon in the sense that it is caused by biological processes, is itself a biological process, and interacts with other biological processes. Consciousness is a biological process like digestion, photosynthesis, or the secretion of bile. Of course, our conscious lives are shaped by our culture, but culture is itself an expression of our underlying biological capacities' $(2002,60)$.

21. A view on permanence (nitya-drstii), which mistakenly holds that, owing to the apprehension of an absolute identity in the uninterrupted continuum occurring in a cause-effect relationship, there is a permanently existing entity or soul (ätman). From a Buddhist perspective, all that can be established is the successive coming into being and cessation of phenomena.

22. A view on annihilation (uccheda-drstit), which mistakenly holds that absolutely nothing exists after life. This view denies the functioning of karma (or moral law) and the workings of cause and effect. Since nothing exists beyond death, one does not need to take responsibility for wrongful actions or consider possible reward for good actions.

23. If not dualism nor physicalism, we might ask whether Buddhism could perhaps then be considered a form of idealism? The answer to this question depends on what we mean by the term 'idealism'. It is true that the various schools of Buddhism hold different views with regard to this matter, however on the level of ultimate truth, clinging to any type of '-ism' would be considered mistaken. Strictly speaking therefore, Buddhism is neither a form of dualism, nor a form of monism such as idealism.

24. 「我施設意業為最重也。」(Chinese Electronic Tripitaka Collection, T01, no. 26, p. $628, \mathrm{c} 4-5)$

25. This view resonates with Immanuel Kant's theory that 'free will' is one of the postulates of morality. It is the very presence of 'free will' that makes morality possible. Similarly, Buddhism holds that the human mind plays a crucial role in the creation of karma. Certain animals may well possess similar biological processes to humans, yet it is not rational to expect them to behave morally. When a lion hunts down an antelope for example, the act of prey is determined by a physical mechanism, hence it would not make sense to expect it to behave more compassionately. By the same token, the problem of morality seems to bear no obvious relevance to ghosts. In the Buddhist scheme of things, the quality of our mental state strongly influences, or even wholly determines, our moral behaviour, thereby deciding whether we continue to remain in the endless cycle of rebirth or achieve the liberated state of nirvana.

26. Rockwell notes: 'The brain dwells in a body, which in turn dwells in a world, and everything that happens to the brain is dependent on the causal relations that bind the brain-body-world together. I am claiming that it is these kinds of causal 
relations that the mind supervenes on, not just the relationships that exist between the neurons in the skull' (Rockwell 2005, 71). He further points out that 'Cartesian materialism' leads us astray because it 'tries to single out one part of the brain-body-world nexus as the only true "seat of the soul"' (Rockwell 2005, 209 n.1).

27. For developments related to the theory of enactionism, see Stewart, Gapenne and Di Paolo 2010; Rowlands 2010; Chemero 2009.

28. Two concepts often used in Chinese Buddhism to illustrate the relation between mind and body are visualizing decaying fake flesh to realize the truth (藉假修真), and viewing the body as a vehicle for understanding reality (以身載道). Both are similar to the analogy of beauty revealed by looking at a painting. Besides, another possible metaphor by which we could explain the relation between mind and body would be the relation between water and $\mathrm{H}_{2} \mathrm{O}$. Although $\mathrm{H}_{2} \mathrm{O}$ can be taken as a molecular representation of water, it is not necessarily capable of representing all the aspects of water. The symbol has no way to account for water's properties of being wet and moistening for example. Moreover, in Buddhism water is usually taken to represent purity, while in the Taoist tradition it portrays an image of being soft and changeable. These are properties which exist over and above the chemical elements $\mathrm{H}_{2} \mathrm{O}$. Still, if it weren't for the presence of hydrogen and oxygen molecules in water, the properties of purity and softness would not become manifest. Therefore, the relation between water and $\mathrm{H}_{2} \mathrm{O}$ is neither identical nor different.

29. This is why various Buddhist traditions place a great deal of emphasis on mental training such as silent contemplation and meditative concentration.

30. This mental skill is similar in many ways to the ability to swim-a skill which cannot be merely picked up through reading or watching instructional videos. It is necessary to enter the water oneself, else any talk of swimming skill remains empty talk on dry land. Although a champion swimmer might possess limited theoretical knowledge of swimming technique, he or she nonetheless usually has practical swimming skills which by far outshine the ability of the coach. Similarly, it is possible to put our mind to good use and pursue a meaningful existence despite having only limited scientific knowledge of the human mind itself.

31. Here, 'psychology' is intended to include both Western and Eastern notions of the term.

32. Or we might say that different approaches to the investigation of mind are 'physically', 'biologically', 'physiologically', 'psychologically', 'ethically', or 'spiritually' studying it.

33. In addition to the mind, body plays an equally important role as the physical manifestation of our mental state and as such provides observable clues to the mind. Mind on the other hand, plays the role of intermediary between a person's current imperfect existence and liberated states of increased happiness. Mind could thus perhaps be seen as a bridge connecting our understanding of the physical world and the world of value. 


\section{REFERENCES}

Chemero, Anthony. 2009. Radical Embodied Cognitive Science. Cambridge, MA: MIT Press.

Chinese Electronic Tripitaka Collection. 2011. April 2011 version. Published by Chinese Buddhist Electronic Text Association (BETA), http://www.cbeta.org/

Clark, Andy. 2008. Supersizing the Mind: Embodiment, Action, and Cognitive Extension. Oxford: Oxford University Press.

Collins, Steven. 1982. Selfless Persons: Imagery and Thought in Theravada Buddhism. Cambridge: Cambridge University Press.

Conze, Edward. 2001. Buddhist Wisdom Books, Containing The Diamond Sutra and The Heart Sutra. New York: Vintage.

Flanagan, Owen. 2007. The Really Hard Problem: Meaning in a Material World. Cambridge, MA: MIT Press.

Griffiths, Paul J. 1986. On Being Mindless: Buddhist Meditation and the Mind-Body Problem. LaSalle, IL: Open Court.

Gombrich, Richard F. 1971. Precept and Practice: Traditional Buddhism in the Rural Highlands of Ceylon. Oxford: Clarendon Press.

Hamilton, Sue. 1996. Identity and Experience: Constitution of the Human Being According to Early Buddhism. London: Luzac Oriental.

Harvey, Peter. 1990. An Introduction to Buddhism: Teachings, History and Practices. Cambridge: Cambridge University Press.

Harvey, Peter. 1993. "The Mind-Body Relationship in Pali Buddhism: A Philosophical Investigation." Asian Philosophy 3 (1): 29-41.

Harvey, Peter. 1995. The Selfless Mind: Personality, Consciousness and Nirvana in Early Buddhism. London: Curzon Press.

Harvey, Peter. 2000. An Introduction to Buddhist Ethics: Foundations, Values and Issues. Cambridge: Cambridge University Press.

Keown, Damien. 2000. Buddhism: A Very Short Introduction. Oxford: Oxford University Press.

Luisi, Pier Luigi, and Zara Houshmand. 2008. Mind and Life: Discussions with the Dalai Lama on the Nature of Reality. New York: Columbia University Press.

Nhat Hanh, Thich. 2007. Buddha Mind, Buddha Body: Walking Toward Enlightenment. Berkeley, CA: Publishers Group West.

Nyanaponika, Thera. 1998. Abhidhamma Studies: Buddhist Explorations of Consciousness and Time. Boston, MA: Wisdom.

Rockwell, W. Teed. 2007. Neither Brain nor Ghost: A Nondualist Alternative to the MindBrain Identity Theory. Cambridge, MA: MIT Press.

Rowlands, Mark. 2010. The New Science of the Mind: From Extended Mind to Embodied Phenomenology. Cambridge, MA: MIT Press.

Ryle, Gilbert. 1949. The Concept of Mind. Chicago, IL: University of Chicago Press.

Searle, John R. 1998. Mind, Language, and Society: Philosophy in the Real World. New York: Basic Books. 
Searle, John R. 2002. "Why I Am Not a Property Dualist." Journal of Consciousness Studies 9 (12): 57-64.

Siderits, Mark. 2007. Buddhism as Philosophy: An Introduction. Cambridge, MA: Hackett. Stevenson, Ian. 1980. Twenty Cases Suggestive of Reincarnation. Virginia: University of Virginia Press.

Stevenson, Ian. 2000. Children Who Remember Previous Lives: A Question of Reincarnation. Jefferson, NC: McFarland \& Co.

Stewart, John, Olivier Gapenne, and Ezequiel A. Di Paolo, eds. 2010. Enaction: Toward a New Paradigm for Cognitive Science. Cambridge, MA: MIT Press.

Streng, Frederick. 1967. Emptiness: A Study in Religious Meaning. New York: Abington. Thiện Châu, Thích. 1999. The Literature of the Personalists of Early Buddhism, Translated by Sara Boin-Webb. Delhi: Motilal Banarsidass.

Tsongkhapa. 2006. Ocean of Reasoning: A Great Commentary on Nagarjuna's Mulamadhyamakakarika. Translated by Jay L. Garfield and Geshe Ngawang Samten. Oxford: Oxford University Press.

Tucker, Jim B. 2008. Life Before Life: Children's Memories of Previous Lives. New York: St Martin's Griffin Press.

Wright, Dale. 2005. "Critical Questions Towards a Naturalized Concept of Karma in Buddhism." Journal of Buddhist Ethics 12: 78-93. http://blogs.dickinson.edu/ buddhistethics/files/2011/01/wright01.pdf

Chien-Te Lin is an Associate Professor at the Institute of Religion and Humanity, Tzu-Chi University, Taiwan.

Address: College of Humanities and Social Sciences, Tzu Chi University, 67 Jie Ren Street, Hualien, Taiwan. Email: bhadanta@gmail.com, d92124002@ntu.edu.tw 